\title{
Pharmacological Management of Urinary Incontinence: Current and Emerging Treatment
}

\section{Carlo Gandi (iD \\ Emilio Sacco}

Department of Urology, Fondazione Policlinico Universitario Agostino Gemelli IRCCS, Catholic University School of Medicine, Rome, Italy
Correspondence: Carlo Gandi; Emilio Sacco

Department of Urology, Fondazione Policlinico Universitario A. Gemelli IRCCS, Catholic University School of

Medicine, Largo Agostino Gemelli, 8, Rome, 00168 , Italy

Tel +393802543254; +390630I55290

Email carlogandi@gmail.com;

emilio.sacco@gmail.com

\begin{abstract}
Pharmacological management of urinary incontinence (UI) is currently based on antimuscarinic and beta-3-agonist drugs. Botulinum toxin A detrusor injections represent an effective but more invasive alternative. This review covers the latest developments of the currently available drugs and the emerging compounds for the treatment of UI. Evidence shows that new antimuscarinics and beta-3-agonists with improved safety profiles may offer unique options to patients intolerant to currently available drugs. Combination therapy proved to be a non-invasive alternative for patients refractory to first-line monotherapy. Exciting advances are ongoing in the research to improve the efficacy/tolerability profile of botulinum toxin, through innovative routes of administration. Several new agents emerged from preclinical studies, some of which have now entered the clinical phase of development and could represent, in the coming years, a new way for the treatment of UI. Recent evidence on the existence of different overactive bladder phenotypes could be the key to tailored treatment. Rather than discovering new molecules, reaching the ability to identify the right drug for the right patient could be the real gamechanger of the future.
\end{abstract}

Keywords: overactive bladder, OAB, urgency, antimuscarinics, beta-3-agonists, botulinum

\section{Introduction}

The International Continence Society (ICS) defined urinary incontinence (UI) as the complaint of any involuntary leakage of urine. ${ }^{1}$ It has been estimated that approximately 20 million women and 6 million men in the United States experience urinary incontinence during their lives. ${ }^{2}$ Urinary incontinence is classified as stress urinary incontinence (SUI), urgency urinary incontinence (UUI), and mixed urinary incontinence (MUI). ${ }^{1}$ SUI is the complaint of involuntary leakage on effort or exertion, or when sneezing or coughing, while UUI is the complaint of involuntary leakage accompanied by or immediately preceded by urgency. MUI is the complaint of involuntary leakage associated with urgency and also with exertion, effort, sneezing, or coughing.

SUI is the most common type of urinary incontinence in women, affecting more than half of all women aged 60 years or more. ${ }^{3}$ SUI is less common in men, where it is often a complication following prostate surgery, such as radical prostatectomy or transurethral resection of the prostate (TURP). ${ }^{4}$ Pharmacologic therapy for SUI is still unsatisfactory ${ }^{5}$ and there is urgent need for novel effective drugs for this condition.

Overactive bladder syndrome (OAB) is characterized by urinary urgency, with or without urgency urinary incontinence, usually with increased daytime frequency and nocturia, if there is no proven infection or other obvious pathology. ${ }^{1} \mathrm{OAB}$ is 
a predominantly chronic condition, affecting especially the elderly population, and associated with a very high socioeconomic burden because of the aging population, related comorbidities, and increased risk of hospitalization. ${ }^{6}$ Multiple pathophysiologic mechanisms have been proposed, such as a primary detrusor dysfunction (observed as detrusor overactivity during urodynamic studies), an overactivity of the afferent arm of the micturition reflex, a urothelial dysfunction and a primary dysfunction of higher central nervous system (CNS) inhibitory centers. ${ }^{7}$ The pharmacological therapy is of utmost importance in the management of $\mathrm{OAB}$ patients, when behavioral therapy fails or allows only partial relief of symptoms. ${ }^{8}$ The availability of several pharmacological principles has stimulated the growth of the global OAB treatment market, with estimates projected to reach USD 4.19 billion by 2022 from USD 3.63 billion in 2017. Antimuscarinic agents have been the mainstay of drug treatment for years, but nowadays beta-3-agonists are recognized as an effective and safe alternative. Botulinum toxin A detrusor injections represent an effective but more invasive option for patient refractory or intolerant to oral drugs. A large number of investigational compounds have been the object of preclinical studies, some of which have advanced to the clinical phase with mixed results.

\section{Evidence Acquisition}

We performed a comprehensive review of peer-reviewed English-language full articles published in the last 5 years. The MEDLINE, Scopus and Web of Science data banks were searched employing both "MeSH" and "free text" protocols and using a combination of the following search terms: "urinary incontinence", "overactive bladder" AND "drug therapy". A search of articles related to each specific compound was also performed. A hand-search of reference lists of retrieved articles was performed in order to identify further studies not captured by the above-used terms. Pharmaceutical companies' sources were searched for pipeline projects. Ongoing and unpublished completed clinical trials were searched in clinicaltrials.gov, controlled-trials.com, clinicaltrialsfeeds.org, nres.nhs.uk, clinicaltrialsregister.eu and eudract.ema.europa.eu.

\section{Antimuscarinics}

Acetylcholine (ACh) released from cholinergic nerves stimulates muscarinic receptors and mediates the main part of voiding contractions in humans. ${ }^{9}$ Five subtypes of muscarinic receptors (M1-M5) have been identified. ${ }^{10}$ The M2 and M3 subtypes have been detected in the human bladder $^{11}$ and, despite the predominance of M2 receptors, several studies reported that pharmacologically defined M3 receptors mediate bladder contraction. ${ }^{12,13}$ Antimuscarinics (AMs) are now widely used as the pharmacological therapy for overactive bladder (OAB) and/or urgency incontinence. Table 1 presents an overview of the most commonly used drugs, which have all demonstrated their efficacy and safety in well-designed, controlled studies.

\section{Adverse Effects}

While anticholinergic agents have proven effective in patients with $\mathrm{OAB}$, they are associated with several bothersome adverse effects (AEs), including dry mouth, constipation, somnolence, drowsiness, and blurred vision, which impact on both compliance and persistence with long-term treatments, ${ }^{14,15}$ dry mouth being the most common.

Although all antimuscarinic drugs are comparable in terms of efficacy, immediate release (IR) oral oxybutynin was associated with more side-effects. ${ }^{16}$ A meta-analysis of AEs showed statistically significant lower rates of dry mouth for extended release (ER) formulations of oxybutynin (40\%) and tolterodine (18\%) compared with the IR formulations of both medications $(68 \%$ and $28.8 \%$, respectively). ${ }^{17}$ Transdermal oxybutynin (patch and gel) showed lower dry mouth rates than the meta-analyzed rates of $40.0 \%$ for oral oxybutynin ER and $68.0 \%$ for oral oxybutynin IR. ${ }^{17}$ So, as other outcomes were similar, and dry mouth is the main reason people give up taking AMs, ER and transdermal formulations may be a good

Table I Characteristics of Antimuscarinic Drugs for Urgency Urinary Incontinence

\begin{tabular}{|l|c|c|}
\hline Medication & Selectivity & Ability to Cross BBB \\
\hline Darifenacin & M3 & Low \\
\hline Fesoterodine & Nonselective & Low \\
\hline Imidafenacin & Predominantly M3 & Low \\
\hline Oxybutynin & Nonselective & High \\
\hline Propiverine & Nonselective & Moderate \\
\hline Solifenacin & Predominantly M3 & Moderate \\
\hline Tolterodine & Nonselective & Moderate \\
\hline Trospium & Nonselective & Low \\
\hline
\end{tabular}

Abbreviation: BBB, blood-brain barrier. 
way to start treatment. ${ }^{18}$ However, among patients using transdermal oxybutynin, skin reactions were the commonest reason for treatment discontinuation. ${ }^{19}$

Neurological AEs are of great concern, particularly in elderly patients because of an increase in blood-brain barrier (BBB) permeability with aging. ${ }^{20,21}$ Recent research suggested an association between higher cumulative anticholinergic use and the risk of Alzheimer disease and dementia. ${ }^{22,23}$ According to Dmochowski et al, ${ }^{24}$ the use of anticholinergic agents for $\geq 3$ months appears to increase the risk of dementia by an estimated $46 \%$ on average compared with nonuse. Evidence regarding cognitive effects of individual AMs is also not uniform. Oral oxybutynin has been associated with cognitive impairment in the elderly in the short term, and along with tolterodine has been associated with a higher risk of incident dementia. ${ }^{22}$ By contrast, short-term studies in older adults have demonstrated little to no cognitive impairment associated with fesoterodine, solifenacin, or trospium. ${ }^{25-27}$ In a randomized, double-blind, placebo-controlled trial, Yonguc et $\mathrm{al}^{28}$ proved that fesoterodine $4 \mathrm{mg}$ in idiopathic Parkinson's disease patients with $\mathrm{OAB}$ improved $\mathrm{OAB}$ symptoms significantly, without statistically significant impairment of cognitive functions compared with placebo.

\section{Latest Developments}

Novel antimuscarinic molecules were developed with the intention of attaining better M3 affinity and improving side-effect profiles.

Imidafenacin (Uritos; Kyorin Pharmaceutical Co, Japan) is a novel antimuscarinic agent used to treat $\mathrm{OAB}$ in Japan since 2007, which has been developed to improve the tolerability of therapy by a higher affinity for the M1 and M3 receptor subtypes and lower affinity for the M2 subtype. A placebo-controlled clinical trial demonstrated the efficacy and safety of imidafenacin for the treatment of OAB in Japanese patients. ${ }^{29}$ A randomized, open-label, tolterodine-controlled trial by Pushkar et al demonstrated the efficacy and safety of imidafenacin in Caucasian patients. ${ }^{30}$ Twelve weeks after starting treatment, the change in the mean number of incontinence episodes was $-2.1 \pm 2.2$ in the imidafenacin group and $-1.9 \pm 1.8$ in the tolterodine group $(\mathrm{p}=0.001)$; the change in the mean number of daytime incontinence episodes was $-1.7 \pm 1.7$ and $-1.5 \pm 1.4(\mathrm{p}=0.01)$. The most frequent drug-associated AEs were gastrointestinal disorders, without significant differences between the groups. A recent systematic review and meta-analysis of all published RCTs comparing imidafenacin with other $\mathrm{ADs}$ by $\mathrm{Wu}$ et al, concluded that imidafenacin and other AMs had similar efficacy, while imidafenacin caused fewer nocturia episodes and showed lower dry mouth rate, lower constipation rate and fewer withdrawals, making imidafenacin preferable for patients who need long-term medications. ${ }^{31}$

Tarafenacin (SVT-40776, by SALVAT and Kwang Dong Pharmaceutical Co. Ltd) is a new quinuclidinol derivative, with the highest selectivity of human M3 vs M2 subtype of any other reference antagonists tested, and with a less marked inhibiting effect on M3 activation in submandibular gland than in bladder, indicating a very favourable selectivity index between both tissues. ${ }^{32}$ Song et al, in a randomized, double-blind, placebo-controlled Phase II study, demonstrated that the improvement in OAB symptoms was greater with tarafenacin $0.4 \mathrm{mg}$ than with placebo. ${ }^{33}$ Interestingly, the rate of dry mouth was somewhat higher for tarafenacin $(64.2 \%)$ than other reported anticholinergics $\left(29.6 \%{ }^{15}\right)$, while the rate of constipation of tarafenacin (2.1\%) was comparatively lower than other agents $\left(7.7 \%{ }^{15}\right)$.

\section{Beta-3-Agonists}

Beta-3 adrenergic receptor ( $\beta 3-\mathrm{AR})$ represents the most common subtype of $\beta$-ARs in the human bladder where it mediates noradrenaline-induced detrusor relaxation. ${ }^{34}$ The development of $\beta 3$-AR agonists was originally aimed at the treatment of diabetes mellitus. An extensive multinational program of clinical development led, in 2012, to the marketing approval of mirabegron (YM178, by Astellas Pharma Inc.), the first oral drug alternative to $\mathrm{AMs}$ for the treatment of OAB. ${ }^{35}$ In several studies mirabegron $50 \mathrm{mg}$ showed comparable overall efficacy versus antimuscarinic treatments, but proved to be significantly better tolerated. ${ }^{36}$ A recent multicenter prospective study (the FAVOR study) concluded that mirabegron significantly improved the rates of treatment satisfaction and symptoms in patients with $\mathrm{OAB}$ who were unsatisfied with prior antimuscarinic treatment. ${ }^{37}$ The response rate of treatment satisfaction at 12 weeks was $69.3 \%$ (275/397).

\section{Adverse Effects}

The most common adverse events (AEs) observed with mirabegron in clinical trials of up to 12 months were hypertension $(7.3 \%)$, nasopharyngitis $(3.4 \%)$, and urinary tract infection $(3.0 \%) .{ }^{35}$ This resulted in a contraindication in the product label of mirabegron for patients with severe 
uncontrolled high blood pressure (systolic $\geq 180 \mathrm{~mm} \mathrm{Hg}$ and/or diastolic $\geq 110 \mathrm{~mm} \mathrm{Hg}$ ), even though data on patients with poorly controlled hypertension, arrhythmia, or cardiac heart failure are currently missing because those patients were excluded from previous studies. ${ }^{38}$ Nevertheless, in an analysis of pooled mirabegron safety data, from over 13,000 patients in 13 studies, there was no evidence of increased cardiovascular risk for mirabegron versus placebo. ${ }^{39}$

Dry mouth rate with mirabegron $50 \mathrm{mg}$ was similar to that with placebo and significantly lower compared with almost all other active treatments, as for constipation and urinary retention. ${ }^{40}$ Treatment persistence with mirabegron was significantly longer than that with AMs when administered as either the first- or second-line medication. ${ }^{41}$

The PILLAR trial evaluated safety and tolerability of mirabegron in patients aged $\geq 65$ years with OAB-wet: ${ }^{42}$ treatment-emergent adverse events (TEAEs), the majority mild or moderate in severity, were reported in $39.4 \%$ of placebo patients and 44.2 and $49.8 \%$ of those who received mirabegron $25 \mathrm{mg}$ or $50 \mathrm{mg}$, respectively, consistent with the known mirabegron safety profile. The most common TEAEs in mirabegron-treated patients were urinary tract infection, headache, and diarrhea. The incidence of TEAEs was slightly higher in mirabegron patients aged $\geq 75$ years than in those aged $<75$ years. The same trial, using the Montreal Cognitive Assessment test (MoCA), highlighted that mirabegron treatment does not contribute to drug-related cognitive side effects. In particular, there was no statistically significant change in adjusted mean MoCA total score from baseline to end-of-treatment in the mirabegron group $(-0.2[0.1])$ or the placebo group $(-0.1$ $[0.1]){ }^{43}$

\section{Latest Developments}

Vibegron (MK-4618, by Urovant Sciences $\mathrm{GmbH}$ ) is a novel, potent, and selective $\beta 3$-AR agonist deriving from MK-0634, a $\beta 3$-AR agonist created for the treatment of obesity in the early 2000s. While efficacy for treatment of obesity was not achieved, the compound was instead pursued for the treatment of OAB, where it demonstrated proof-of-concept in humans. ${ }^{44}$ In a double-blind, placebocontrolled Phase 3 RCT, Yoshida et al demonstrated that vibegron $50 \mathrm{mg}$ (V50) and $100 \mathrm{mg}$ (V100) once daily for 12 weeks provided superior efficacy over placebo in the treatment of Japanese patients with OAB. ${ }^{45}$ The estimated differences in mean micturitions/d, urgency incontinence episodes/day and incontinence episodes/day between the vibegron groups and placebo were $-0.86,-0.27$ and -0.30 , respectively, for V50 $(\mathrm{p}<0.001)$ and $-0.81,-0.39$ and -0.43 , respectively, for $\mathrm{v} 100(\mathrm{p}<0.001)$. The most common drug-related TEAEs of vibegron were dry mouth and constipation; however, the incidence of dry mouth was similar to placebo. A post hoc analysis of the same $\mathrm{RCT}^{46}$ vibegron significantly reduced the number of UUI episodes/day and significantly increased the voided volume/micturition in patients with $\mathrm{OAB}$, with a response rate exceeding $50 \%$. Changes in numbers of UUI episodes at week 12 in the V50, V100 and placebo groups, respectively, were $-1.35,-1.47$ and -1.08 in all patients and $-2.95,-3.28$ and -2.10 in the severe UUI subgroup.

An international Phase IIb dose finding RCT in the Caucasian population also concluded that once-daily V50 and V100 improved OAB symptoms. ${ }^{47}$ A recent Phase III randomized, double-blind, placebo and active controlled study, found that once daily $75 \mathrm{mg}$ vibegron (V75) provided statistically significant reductions in micturitions, urgency episodes and urgency incontinence, and increased the volume per micturition. ${ }^{48}$ At 12 weeks, urgency incontinence episodes decreased by an adjusted mean 2.0 episodes per day for V75 vs 1.4 for placebo $(\mathrm{p}<0.0001)$ and 1.8 for tolterodine. At 12 weeks, the proportion of wet $\mathrm{OAB}$ cases with $75 \%$ or greater reduction from baseline in UUI episodes per day was $52.4 \%$ in the V75 group vs $36.8 \%$ in the placebo group $(\mathrm{p}<0.0001)$. For tolterodine, the proportion was $47.6 \%$. Vibegron showed a favorable safety profile, with the same incidence of hypertension as placebo (1.7\%).

With regard to the safety profile, it is known that mirabegron inhibits CYP2D6, a cytochrome P450 (CYP450) enzyme, so drug-drug interaction should be considered, while vibegron did not show any induction and inhibitory effects on CYP enzymes, suggesting no risk of drug-drug interaction. ${ }^{49}$

Vibegron received approval, for OAB treatment, from the Japanese PMDA in September 2018 and by the American FDA in December 2020.

In the absence of head-to-head trials, Kennely et al performed an indirect treatment comparison of vibegron and mirabegron. ${ }^{50}$ Vibegron was associated with significantly greater improvement from baseline in total incontinence episodes versus mirabegron at 4 and 52 weeks $(p<0.05$, each) and volume voided at 12 and 52 weeks $(p<0.05$, each). Incidence of AEs was generally comparable. 
Solabegron, formerly known as GW427343, is a highly selective $\beta 3$-AR agonist, developed for the treatment of $\mathrm{OAB}$ and irritable bowel syndrome. In a randomized, double-blind, proof-of-concept study, Ohlstein et al evaluated the efficacy and safety of solabegron $50 \mathrm{mg}$ and $125 \mathrm{mg}$ administered twice daily compared to those of placebo in women with $\mathrm{OAB} .{ }^{51}$ Solabegron $125 \mathrm{mg}$, compared to placebo, produced a statistically significant difference in percentage change from baseline to week 8 in incontinence episodes over $24 \mathrm{~h}(\mathrm{p}=0.025)$, showed significant reductions from baseline to weeks 4 and 8 in micturitions over $24 \mathrm{~h}(\mathrm{p}<0.05)$ and a significant increase from baseline to week 8 in urine volume voided $(\mathrm{p}<0.05)$. Solabegron was well-tolerated and did not demonstrate significant differences in AEs as compared to placebo. In particular, there were no significant treatment differences for mean changes from baseline to week 8 in blood pressure or heart rate during the 24-h ambulatory measurement.

Ritobegron (KUC-7483 by Kissei Pharmaceutical Co., Ltd. Matsumoto, Nagano, Japan) is a novel $\beta 3$-AR agonist, whose effects on rat bladder function and salivary secretion were investigated by Maruyama et al in comparison with tolterodine. ${ }^{52}$ After a 6-week partial bladder outlet obstruction (BOO), drug effects on bladder functions were evaluated using cystometrography. Ritobegron decreased both the frequency and amplitude of non-voiding contractions (NVC), without affecting micturition pressure, residual volume, or carbachol-induced salivary secretion. Although tolterodine reduced the amplitude of NVC, it also markedly increased residual volume and significantly inhibited carbachol-induced salivary secretion.

\section{Phosphodiesterase-5 Inhibitors}

Phosphodiesterase 5 inhibitors (PDE5i) have traditionally been used in the treatment of erectile dysfunction. PDE-5i prolong the physiological effects of nitric oxide (NO)/cyclic guanosine monophosphate (cGMP) signaling in tissues through the inhibition of cGMP degradation, an important mediator of smooth muscle tone. ${ }^{53}$ In several studies, 5-PDEi, particularly tadalafil, showed a potential therapeutic use in the treatment of OAB and male LUTS. Evidence from animal studies suggested that the decrease in urinary $\mathrm{NO}$ and detrusor cGMP levels can lead to the inhibition of detrusor relaxation inducing bladder overactivity. ${ }^{54}$

The recent results of Lee et al, in rats with metabolic syndrome, indicated that daily tadalafil intake may ameliorate bladder overactivity through the increase of nitric oxide synthase (eNOS) activity in bladder mucosa, and the restoration of urinary NO availability and detrusor cGMP level. ${ }^{55}$

In a prospective $\mathrm{RCT}$ in men $>65$ years with $\mathrm{OAB}$, Dell'Atti showed that tadalafil $5 \mathrm{mg} / \mathrm{d}$, when compared with fesoterodine $8 \mathrm{mg} / \mathrm{d}$, significantly improved urgency incontinence episodes $(1.7 \pm 1.3$ to $0.5 \pm 1.3$ vs $1.7 \pm 1.3$ to $1.0 \pm 1.4 ; \mathrm{p}<0.001)$. In addition, erectile function and QoL scores also improved to a greater extent in the tadalafil group. ${ }^{56}$

Similarly, a double-blind, placebo-controlled RCT in women with $\mathrm{OAB}$, by Chen et al, indicated that tadalafil $5 \mathrm{mg} / \mathrm{d}$ significantly improved frequency, urgency, and incontinence episodes compared with placebo. ${ }^{57}$ Tadalafil $5 \mathrm{mg} / \mathrm{d}$ was well-tolerated and no serious adverse reaction was observed, possibly due to the low doses of the drug.

\section{Latest Developments}

Gisandenafil (UK-369003, by Pfizer) is a novel PDE5i, whose modified release (MR) formulation was investigated as a treatment for men with clinical diagnosis of $\mathrm{OAB}$, in a multicenter, double-blind, placebo-controlled RCT conducted by Giuliano et al. ${ }^{58}$ Unfortunately, there were no clinically relevant treatment differences in voiding frequency, mean voided volume, urgency episode frequency, or nocturia frequency for any dose of UK369003 MR compared with placebo.

\section{Combination Therapy}

As in the management of other medical conditions (such as refractory hypertension, benign prostatic hyperplasia, and cancer treatments), the combination of different drugs is thought to have a role in the setting of refractory $\mathrm{OAB} / \mathrm{UI}$ and is increasingly used in clinical practice. Combination therapy's advantage lies in acting simultaneously on different pharmacological pathways, with additive and/or synergistic effects.

The most studied combination therapy is that of an anticholinergic medication with mirabegron. The three largest RCTs on the subject were the BESIDE, SYNERGY, and SYMPHONY studies and all demonstrated that combination therapy of solifenacin with mirabegron improves, in a statistically significant manner, urinary frequency, urgency, and urgency incontinence compared to monotherapy solifenacin or mirabegron alone. ${ }^{59-61}$ In particular, Drake et al (BESIDE) evaluated mirabegron add-on therapy to solifenacin in incontinent overactive bladder patients with an inadequate response to initial 4-week solifenacin monotherapy. ${ }^{59}$ They found that 
adding mirabegron $50 \mathrm{mg}$ to solifenacin $5 \mathrm{mg}$ further improved OAB symptoms versus solifenacin 5 or $10 \mathrm{mg}$, with significantly more patients becoming dry with combination $(46.0 \%)$ versus solifenacin $5 \mathrm{mg}(37.9 \%)$ and $10 \mathrm{mg}$ (40.2\%). In a prespecified analysis from the BESIDE study, Gibson et al found that efficacy and safety in the overall population is maintained in older ( $>65 \mathrm{yr}$ ) and elderly $(>75 \mathrm{yr})$ patients treated with a combination of solifenacin and mirabegron. ${ }^{62}$

In the CONTACT study, Yamanishi et al evaluated the efficacy of the combination of tadalafil and mirabegron versus tadalafil monotherapy for the treatment of persistent overactive bladder symptoms in men. ${ }^{63}$ The total OAB symptoms score of combination therapy was significantly decreased by 1.78 (95\% CI 1.05-2.50) points compared with that of monotherapy $(\mathrm{p}<0.001)$.

Alternative strategies, in patients refractory to first-line antimuscarinic monotherapy, are combination of two antimuscarinics or antimuscarinic cycling (patients who alternate several anticholinergic molecules one after the other). Wang et al evaluated the efficacy and safety of combining two different antimuscarinic drugs by flexibly adding on oxybutynin ER (5-15 mg once a day) in 129 patients refractory to monotherapy. ${ }^{64}$ At three months, 25 (19.4\%) patients reported successful therapeutic effect, but only $31(24.0 \%)$ patients continued the combined medication for up to 12 months. Discontinuation of the combined medication was due to $\mathrm{AE}$ in 28 (21.7\%) patients. Kosilov et al demonstrated that, compared to placebo, combinations of trospium and solifenacin result in decreases in urinary urgency and urgency incontinence. ${ }^{65}$ In particular, one-year cyclic therapy with a trospium and solifenacin combination provided a high compliance level (76-84\%), while continuous therapy with standard doses of trospium and solifenacin resulted in low adherence and high rates of treatment withdrawal $(\geqslant 66 \%)$ despite satisfactory clinical and urodynamic results. Chancellor et al, based on a one-time crosssectional survey of 620 patients with wet-OAB, assessed that UI symptom burden did not change as patients attempted more anticholinergic therapies, suggesting that, for patients who remain incontinent after attempting an anticholinergic, cycling on additional anticholinergics may not provide any additional benefit. ${ }^{66}$

\section{Botulinum Toxin}

There are seven subtypes of botulinum toxin (BoNT), of which subtype A (BoNT-A) is clinically the most relevant. Four different commercial forms of BoNT-A are available: onabotulinumtoxinA, abobotulinumtoxinA, incobotulinumtoxinA and prabotulinumtoxinA. The majority of preclinical and clinical studies have focused on onabotulinumtoxinA (Botox ${ }^{\circledR}$, Allergan, Inc., Irvine, CA). OnabotulinumtoxinA (onaBoNT-A) intradetrusor injections are currently the only FDA approved botulinum toxin treatment for patients with $\mathrm{OAB}$ and/or UUI, who have failed first-line pharmacological treatment. The mechanism of action of BoNT in the nerve terminals has been well-established: BoNT protease activity degrades the SNARE complex protein SNAP-25, thus preventing neurosecretory vesicles from docking/fusing and releasing $\mathrm{ACh}$ and other neurotransmitters from the axon endings, with a long-lasting neuronal blockade leading to decreased muscle contractility and chemical denervation at the injection site. ${ }^{67}$

The efficacy and safety of onaBoNT-A for OAB and urgency incontinence was established by two Phase III, randomized, placebo-controlled trials, leading to the approval of a treatment starting dose of $100 \mathrm{U}(10 \mathrm{~mL})$ in patients with idiopathic OAB. ${ }^{68,69}$ OnaBoNT-A showed significantly greater reductions in UI than AMs in both patients with idiopathic $\mathrm{OAB}^{70}$ and patients with neurogenic $\mathrm{OAB} .{ }^{71}$

A 3.5-year study including patients who received up to 6 treatment administrations assessed that the treatment is repeatable, being safe and effective even in the long term. ${ }^{72}$ Median duration of effect was 7.6 months. The most common adverse event was urinary tract infection (17\% after the first treatment). De novo catheterization after the first treatment was $4.0 \%$ and ranged from $0.6 \%$ to $1.7 \%$ in subsequent treatments. Discontinuations due to lack of efficacy or treatment-related AEs were $5.7 \%$ and $0.5 \%$, respectively.

A recent network meta-analysis compared the efficacy and safety of mirabegron and onaBoNT-A in the management of antimuscarinic-experienced patients with $\mathrm{OAB},{ }^{73}$ finding that onaBoNT-A was associated with improved outcomes, including reductions in the number of incontinence episodes. However, mirabegron was associated with a lower risk of urinary tract infections compared with onaBoNT-A.

Abobotulinumtoxin A (Dysport ${ }^{\circledR}$, Ipsen Biopharm Ltd, Slough, UK) use for the treatment of OAB and UUI is not approved by FDA, because of the lack of supporting large multicenter randomized controlled trials. However, intradetrusor injections of abobotulinumtoxin A (aboBoNT-A) have been reported to be a viable option in several series. ${ }^{74}$ 
Peyronnet et al compared the outcomes of the first intradetrusor injections of aboBoNT-A 750U and onaBoNT-A 200 and $300 \mathrm{U}$ in 211 patients with neurogenic detrusor overactivity. ${ }^{75}$ Patients treated with aboBoNT-A 750U had higher success rates compared to those who received onaBoNT-A 200U (65.4\% vs $41.5 \%$; $p=0.007$ ), while there were similar success rates in aboBoNT-A 750U and onaBoNT-A 300U groups (65.4\% vs $65 \% ; \mathrm{p}=0.91)$ but with a trend towards longer intervals between the first and the second injection in the onaBoNT-A 300U group (12.4 vs 9.3 months; $p=0.09$ ). In a multicenter study including 57 patients, Bottet et al found that switching to aboBoNT-A may be useful in the treatment of neurogenic detrusor overactivity when intradetrusor injections of onaBoNT-A failed. ${ }^{76}$ A significant decrease in number of UI episodes per day was observed in $52.63 \%$ of patients $(\mathrm{p}<0.001)$, maximum cystomanometric capacity significantly increased by a mean of $41.2 \mathrm{~mL}(\mathrm{p}=0.02)$ and the proportion of patients with no uninhibited detrusor contractions increased significantly at week 6 after aboBoNT-A injections (from $15.79 \%$ to $43.9 \%$; $p=0.0002$ ).

\section{Latest Developments}

In recent years, there has been growing interest in the search for new drug delivery approaches (Figure 1), based on the finding that the potency of intradetrusor onaBoNT-A injections is sensitive to injection volume and depth. ${ }^{77}$

Liposomes (lipid vesicles) have been widely studied as a drug delivery tool for anticancer drugs, and several such products are now FDA approved. In vitro studies found that onaBoNT-A complexed with liposomes was protected from proteolytic degradation exerted by urine proteases. ${ }^{78}$ As such, after convincing results of tests in animal models, ${ }^{79}$ a multi-center placebo controlled trial was conducted to assess the safety and efficacy of onaBoNT-A complexed with liposomes in men and women with $\mathrm{OAB}^{80}$ At 4 weeks after treatment, lipo-botulinum toxin instillation was associated with a statistically significant decrease in micturition events per 3 days $(-4.64$ vs -0.19 for placebo, $\mathrm{p}=0.02$ ) and statistically significant decrease in urgency severity scores compared to placebo $(\mathrm{p}=0.01)$, with no urinary retention events and with a risk of UTI similar to placebo.

Intravesical thermosensitive hydrogels have been developed to increase the residence time of drugs within the bladder. The unique rheological property of thermosensitive hydrogels allows the instillation to be liquid at room temperature of $25^{\circ} \mathrm{C}$, and then semi-solid at body temperature. $^{81}$ A clinical study of TC-3 Gel/BTX-A

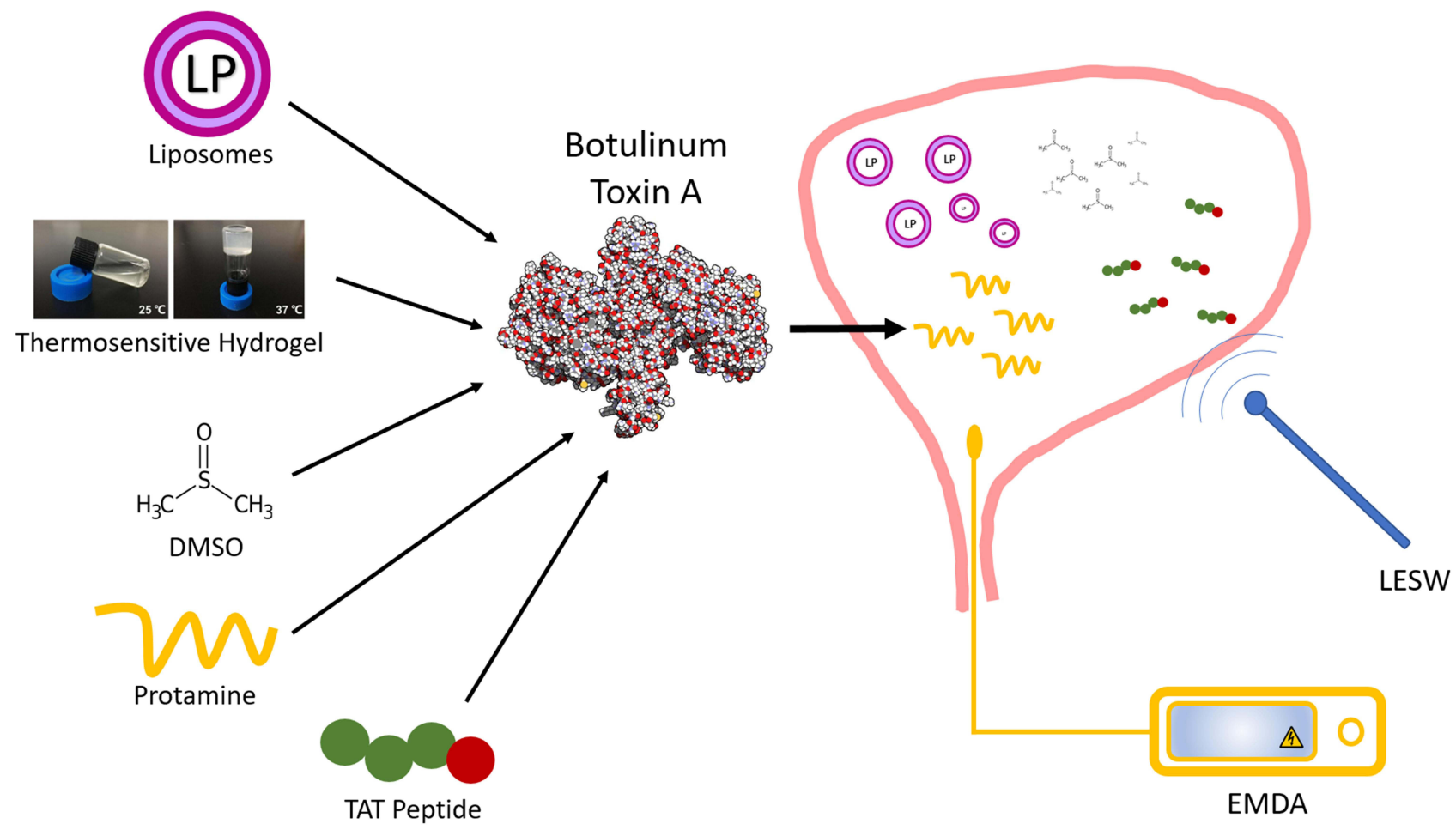

Figure I Different approaches for intravesical delivery of botulinum toxin.

Abbreviations: DMSO, dimethyl sulfoxide; EMDA, electromotive drug administration; LESW, low energy shock waves. 
mixture reported that thermosensitive hydrogel improved the intravesical delivery of onaBoNT-A in patients with painful bladder syndrome. ${ }^{82}$ The hydrogel within the bladder allowed a gradual release of 200U of onaBoNT-A for up to 6-8 hours, beyond the typical 2 hours for saline instillation. Preliminary results suggested temporary efficacy lasting for a few weeks, with transient and mild AEs, the most common being constipation.

Dimethyl sulfoxide (DMSO) is an organic solvent that has been used to facilitate delivery of several anticancer drugs into animal bladders by increasing urothelium permeability. ${ }^{83}$ In the work of Petrou et al, 25 women with idiopathic $\mathrm{OAB}$ refractory to antimuscarinics were given onaBoNT-A mixed with DMSO (OnaBoNT-A 300U mixed with $50 \mathrm{~mL}$ of $50 \%$ DMSO was given to 22 patients and two-thirds of that dose was given to 3 patients). ${ }^{84}$ The median number of UUI episodes decreased from 4 at baseline to 2 at 1 month $(p=0.004)$ and then increased back to 4 at 3 months. Also, significant reduction in symptom scores from baseline was noted, and no serious AEs were noted.

Protamine is an arginine-rich polycationic peptide used as an antidote to heparin overdoses and as a complexing agent for long-acting insulin. Protamine internalizes into cells through heparin sulfate mediated endocytosis and several studies have noted that protamine instillation at concentrations of $10-30 \mathrm{mg} / \mathrm{mL}$ denudes the urothelium. ${ }^{85}$ This effect on the urothelium was used to enhance the uptake of onaBoNT-A into the bladders of spinal cordinjured rats. ${ }^{86}$ Protamine belongs to a family of cationic peptides that cross membranes through protein transduction. Small sections of these proteins (10-16 residues long) are responsible for protein transduction domains (PTDs). ${ }^{87}$

PTDs cross membranes through protein transduction, facilitating the transport of fused materials across cellular membranes. ${ }^{88}$ PTDs can be linked covalently to onaBoNTA to facilitate their entry into any cell type independent of receptors and transporters. TAT peptide is a PTD derived from human immunodeficiency virus (HIV), which was successfully employed for the uptake of peptide nucleic acids, conjugated with TAT peptide, into rat bladders. ${ }^{89}$ Therefore, intravesical delivery of onaBoNT-A into the bladder, following conjugation with TAT peptide, can be easily envisioned.

Revance Therapeutics (Newark, CA, USA) developed a successful transdermal delivery of onaBoNT-A conjugated to PTDs, as a gel application that proved to reduce skin wrinkles in 45 patients by $44.5 \% .^{90}$

Electromotive drug administration (EMDA) is a physical approach to increase bladder permeability to instilled drug molecules through electromotive forces (EMF). EMF involves the placement of electrodes, one inside the bladder and one outside on the abdomen to create a potential difference driving the diffusion of instilled drugs. This way of BoNT-A delivery (BoNTA/ EMDA) was evaluated for the treatment of refractory neurogenic detrusor overactivity in 15 children who were given $10 \mathrm{IU} / \mathrm{kg}$ of electromotive BoNT-A. ${ }^{91}$ While connected to a specifically designed indwelling catheter and 2 dispersive pads, a pulsed current generator delivered 10 $\mathrm{mA}$ for 15 minutes. At after-treatment urodynamics, maximal bladder capacity increased considerably (121 \pm $39 \mathrm{~mL}$ vs $262 \pm 41 \mathrm{~mL} ; \mathrm{p}<0.001$ ), while mean maximal detrusor pressure and end-fill pressure significantly decreased $(75 \pm 16 \mathrm{cmH} 2 \mathrm{O}$ vs $39 \pm 10 \mathrm{cmH} 2 \mathrm{O}$ and $22 \pm$ $7 \mathrm{cmH} 2 \mathrm{O}$ vs $13 \pm 2 \mathrm{~cm} \mathrm{H} 2 \mathrm{O}$ ). Urinary incontinence improved in 12 patients $(80 \%)$. Also, fecal incontinence was alleviated in $10(83.3 \%)$ of the 12 children. Skin erythema and burning sensation were observed in 6 children. Kajbafzadeh et al, in an animal study, found that BoNTA can be detected in bladder and bowel structures as well as upper and lower spinal cord following intravesical BoNTA/EMDA, via trans-axonal retrograde transfer mechanism. $^{92}$ This novel mechanism of action can justify the simultaneous improvement in bladder and bowel functions found in children.

Another route of administration based on increasing cell permeability involves low energy shock wave (LESW). According to Kodama et al, LESW can cause shear forces generated by movement of liquid relative to cells, thereby increasing the permeability of the plasma membrane. ${ }^{93}$ Chuang et al investigated the feasibility of using LESW for intravesical BoNT-A delivery, and evaluated its efficacy for acetic acid induced bladder hyperactivity in rats. ${ }^{94}$ Rats that received BoNT-A plus LESW showed a significantly reduced response $(48.6 \%$ decreased intercontraction interval) to acetic acid instillation without compromising voiding function.

\section{Duloxetine}

Duloxetine inhibits the presynaptic re-uptake of serotonin (5-HT) and norepinephrine (NE). In the sacral spinal cord, an increased concentration of 5-HT and NE in the synaptic cleft increases stimulation of 5-HT and NE receptors on 
the pudendal motor neurons, which in turn increases the resting tone and contraction strength of the urethral striated sphincter. ${ }^{95}$ Recently, Wrobel et al found, in a rat model study, that duloxetine reverses the symptoms of overactive bladder co-existing with depression acting via the central pathways, whereas solifenacin and mirabegron act mainly via peripheral pathways. ${ }^{96}$ Duloxetine has been investigated as a means of relieving SUI in adult patients, for temporary improvement or when surgery cannot be used. A cure rate of $10 \%$ may be achieved with doses of $80 \mathrm{mg} / \mathrm{d}$ but with inconsistent data concerning QoL improvement. ${ }^{97}$ Long-term treatment was characterized by a high patient withdrawal rate, caused by a lack of efficacy and high incidence of adverse events, including nausea and vomiting ( $40 \%$ or more of patients). ${ }^{98}$ In a single-blinded interventional randomized clinical trial, involving 60 female patients with idiopathic OAB, Mirzae et al evaluated efficacy and safety of duloxetine $20 \mathrm{mg}$ /daily compared with solifenacin $10 \mathrm{mg} /$ daily. ${ }^{99}$ One month after treatment start, duloxetine and solifenacin showed comparable efficacy, with no statistically significant difference ( $p$-value $=0.148$ ) in the mean ICIQ-OAB questionnaire score (duloxetine vs solifenacin: 8.76 vs 9.66 from 13.90 vs 14.86 before treatment). The prevalence of AEs (dry mouth, blurred vision, anorexia, sleep disturbance, and anxiety) were higher in the solifenacin group, but only the frequency of blurred vision was statistically significant ( $\mathrm{p}$-value $=0.042$ ).

\section{New Agents}

Table 2 provides an overview of the most attractive new agents for pharmacological treatment of urinary incontinence.

DA-8010 (by the Dong-A ST Pharmaceutical Company, Yongin, Korea) is a novel, highly potent M3 antagonist, which appeared more highly selective for the urinary bladder over the salivary glands, large intestine and heart in preclinical studies compared with other antimuscarinic agents. ${ }^{100}$ In the work of Choi et al, oral administration of DA-8010 improved findings in an OAB rat model induced by partial BOO. ${ }^{101}$ In a recent randomized, double-blind, human Phase II study, a total of 306 patients $(69.93 \%$ female) were randomized to 12 weeks of treatment in 1 of 4 groups: two experimental groups (DA8010 $2.5 \mathrm{mg}$ or $5 \mathrm{mg}$ ), an active reference group (solifenacin $5 \mathrm{mg}$ ), or a placebo group. ${ }^{102}$ The mean values (standard deviation) of the changes $(\Delta)$ in $24 \mathrm{hr}$ frequency at 12 weeks were -1.01 (2.44) for placebo, -1.22 (2.05) for DA8010 $2.5 \mathrm{mg}$, and -1.67 (2.25) for
DA8010 $5 \mathrm{mg}$, with a significant difference between DA8010 $5 \mathrm{mg}$ and placebo $(\mathrm{p}=0.0413)$. In the solifenacin $5 \mathrm{mg}$ group, $\Delta 24 \mathrm{hr}$ frequency at 12 weeks was -1.56 (2.17), showing no significant difference from either DA8010 2.5 $\mathrm{mg} \quad(\mathrm{p}=0.4098)$ or DA8010 $5 \mathrm{mg}$ $(\mathrm{p}=0.8540)$. AEs were observed in $3.95 \%$ of placebo, $6.67 \%$ of DA8010 $2.5 \mathrm{mg}, 18.42 \%$ of DA8010 $5 \mathrm{mg}$, and $17.33 \%$ of solifenacin $5 \mathrm{mg}$ groups.

URO-902 (hMaxi-K) is a nonviral, double-stranded, naked plasmid DNA vector expressing the human big potassium (BK) channel $\alpha$ subunit. $^{103} \mathrm{BK}$ channel is highly expressed on urinary bladder smooth-muscle cells and regulates bladder detrusor muscle function. Activation of the BK channel reduces smooth-muscle cell excitability. Two Phase I double-blind, placebo-controlled trials (NCT00495053 and NCT01870037) were performed in healthy women with OAB and urodynamically demonstrated DO, evaluating safety and potential efficacy of URO-902 administered, respectively, by intravesical instillation (ION-02) and direct injection into the bladder wall (ION-03). ${ }^{103}$ Among the safety outcomes, there were no dose-limiting toxicities or significant AEs during either trial, and no participants withdrew due to AEs. For efficacy, in ION-02 ( $=21)$, involuntary detrusor contractions and mean urgency incontinence episodes showed a downward trend at 24 weeks; in ION-03 ( $N=13)$, significant reduction versus placebo in urgency episodes and number of voids were observed 1 week after injection.

SN003 is a reversible antagonist of CRF1, a G-protein coupled receptor of corticotropin-releasing factor (CRF). The CRF family of peptides and receptors coordinates the mammalian endocrine, autonomic, and behavioral responses to stress, and are expressed both peripherally and in the central nervous system with high expression in areas that control voiding (Barrington's nucleus). Inhibition of CRF1 was found to improve cystometric parameters in a model of DO. ${ }^{104}$ In a recent study by Wrobel et al, SN003 attenuated changes in almost all cystometric parameters in rats with induced DO, proving its potential as a treatment for wet OAB. ${ }^{105}$

KPR-5714 is a novel and selective transient receptor potential melastatin 8 (TRPM8) antagonist. TRPM8 channels, responding to cold temperature and/or chemical agents, are mainly expressed in the primary afferent neurons. Previous studies ${ }^{106}$ revealed that the TRPM8 channels may contribute to the pathophysiological bladder afferent hyperactivity via mechanosensitive $\mathrm{C}$ fibers. Aizawa et al investigated the effects of TRPM8 antagonist 
Table 2 Overview of the Most Attractive New Agents for Pharmacological Treatment of Urinary Incontinence

\begin{tabular}{|c|c|c|c|c|c|c|c|}
\hline References & Agent & $\begin{array}{l}\text { Molecular } \\
\text { Pathway }\end{array}$ & $\begin{array}{c}\text { Drug } \\
\text { Component }\end{array}$ & Localization & $\begin{array}{l}\text { Effect } \\
\text { on } \\
\text { Bladder } \\
\text { Activity }\end{array}$ & $\begin{array}{l}\text { Experimental } \\
\text { Phase }\end{array}$ & Notes \\
\hline $\begin{array}{l}\text { Lee et al; } \\
\text { Choi } \\
\text { et al; }{ }^{101} \text { Son } \\
\text { et } \text { al }^{102}\end{array}$ & DA-8010 & $\begin{array}{l}\text { Cholinergic } \\
\text { system }\end{array}$ & $\begin{array}{l}\text { M3 receptor } \\
\text { antagonist }\end{array}$ & $\begin{array}{l}\text { Bladder } \\
\text { smooth- } \\
\text { muscle and } \\
\text { urothelial } \\
\text { cells }\end{array}$ & Inhibitory & Human Phase II & $\begin{array}{l}\text { Highly selective for the urinary } \\
\text { bladder over salivary glands, } \\
\text { intestine and heart }\end{array}$ \\
\hline $\begin{array}{l}\text { Rovner } \\
\text { et al }\end{array}$ & URO-902 & $\begin{array}{c}\text { Big } \\
\text { potassium } \\
\text { (BK) } \\
\text { channels }\end{array}$ & $\begin{array}{l}\text { Plasmid DNA } \\
\text { vector } \\
\text { expressing BK } \\
\text { channel } \alpha \\
\text { subunit }\end{array}$ & $\begin{array}{l}\text { Bladder } \\
\text { smooth- } \\
\text { muscle cells }\end{array}$ & Inhibitory & Human Phase I & $\begin{array}{l}\text { No significant AEs; significant } \\
\text { reduction in urgency and UUI } \\
\text { episodes }\end{array}$ \\
\hline $\begin{array}{l}\text { Wróbel } \\
\text { et al }{ }^{105}\end{array}$ & SN003 & $\begin{array}{l}\text { CRF } \\
\text { peptides and } \\
\text { receptors }\end{array}$ & $\begin{array}{c}\text { Reversible } \\
\text { antagonist of } \\
\text { CRFI }\end{array}$ & $\begin{array}{l}\text { CNS (pontine } \\
\text { micturition } \\
\text { center) }\end{array}$ & Inhibitory & Animal & $\begin{array}{l}\text { Improved cystometric } \\
\text { parameters in a rat model of DO }\end{array}$ \\
\hline $\begin{array}{l}\text { Aizawa } \\
\text { et al }{ }^{107}\end{array}$ & KPR-57I4 & $\begin{array}{l}\text { TRPM8 } \\
\text { channels }\end{array}$ & $\begin{array}{c}\text { TRPM8 } \\
\text { antagonist }\end{array}$ & $\begin{array}{l}\text { PNS (bladder } \\
\text { afferent } \\
\text { nerves) }\end{array}$ & Inhibitory & Animal & $\begin{array}{l}\text { Combination of KPR-57I4 and } \\
\beta 3-A R \text { agonist or AM additively } \\
\text { reduced bladder contractions } \\
\text { and voiding frequency }\end{array}$ \\
\hline $\begin{array}{l}\text { Wróbel } \\
\text { et al }{ }^{110}\end{array}$ & $0-1602$ & $\begin{array}{l}\text { Cannabinoid } \\
\text { receptor }\end{array}$ & $\begin{array}{l}\text { GPR55 and } \\
\text { GPRI8agonist }\end{array}$ & Bladder & Inhibitory & Animal & $\begin{array}{l}\text { Alleviates DO without impairing } \\
\text { voiding function, in rats }\end{array}$ \\
\hline $\begin{array}{l}\text { Aizawa } \\
\text { et al }\end{array}$ & Retigabine & $\begin{array}{l}\text { Voltage- } \\
\text { gated } \\
\text { potassium } \\
\text { channels } \\
\text { (Kvs) }\end{array}$ & $\begin{array}{l}\text { Kv7 Channel } \\
\text { Activator }\end{array}$ & $\begin{array}{l}\text { Bladder } \\
\text { smooth- } \\
\text { muscle cells }\end{array}$ & Inhibitory & Animal & $\begin{array}{l}\text { Inhibited the frequency of RBCs } \\
\text { and mechanosensitive primary } \\
\text { bladder afferent activities, in rats }\end{array}$ \\
\hline $\begin{array}{l}\text { OVADER } \\
\text { Trial; }^{114} \\
\text { Ford et al }^{116}\end{array}$ & Eliapixant & $\begin{array}{l}\text { P2 purinergic } \\
\text { receptor } \\
\text { family }\end{array}$ & $\begin{array}{l}\mathrm{P} 2 \times 3 \\
\text { receptor } \\
\text { antagonist }\end{array}$ & $\begin{array}{l}\text { Bladder and } \\
\text { PNS (bladder } \\
\text { sensory } \\
\text { nerves) }\end{array}$ & Inhibitory & Human Phase I & $\begin{array}{l}\text { Antagonized bladder overactivity } \\
\text { in rats. Research on humans is } \\
\text { ongoing }\end{array}$ \\
\hline
\end{tabular}

Abbreviations: AEs, adverse effects; UUI, urgency urinary incontinence; DO, detrusor overactivity; CRF, corticotropin-releasing factor; CNS, central nervous system; PNS, peripheral nervous system; $\beta 3-A R$, beta3-adrenergic receptor; AM, antimuscarinic; TRPM, transient receptor potential cation channel subfamily $M$ (melastatin); GPR, $\mathrm{G}$ protein-coupled receptor.

combined with $\beta 3$-adrenoceptor agonist or anticholinergic agent on rats with $\mathrm{OAB}$, demonstrating that the combined administration of KPR-5714 and mirabegron or tolterodine tartrate additively reduced bladder contractions and voiding frequency, in comparison with monotherapy. ${ }^{107}$

O-1602 is a novel agonist of GPR55 and GPR18 cannabinoid receptors which are expressed in the bladder and involved in the peripheral modulation of bladder afferent information. ${ }^{108}$ Several clinical trials have indicated that oral agents which modulate cannabinoid receptor activity might be an alternative therapy for patients with OAB. ${ }^{108,109}$ Wrobel et al found that O-1602 does not affect the cystometric parameters in normal rats, but alleviates/ reverses the changes in cystometric and biochemical parameter characteristic of $\mathrm{DO} / \mathrm{OAB}$, affecting the storage phase without impairing the voiding phase in rats with DO. ${ }^{110}$

Kv7 voltage-gated potassium channels have been suggested to modulate mechano-afferent transduction and nociception in the bladder. ${ }^{11}$ Aizawa et al investigated the effects of retigabine, a Kv7 channel activator, on rhythmic bladder contractions (RBCs) and single-unit afferent activities of the primary bladder mechanosensitive afferent nerve fibers in rats. ${ }^{112}$ They demonstrated that retigabine could inhibit the frequency of RBCs and 
mechanosensitive primary bladder afferent activities, suggesting that activation of $\mathrm{Kv} 7$ channels may be a promising tool for modulating bladder hypersensitive disorders such as OAB.

Eliapixant (formerly BAY 1817080, by Bayern) is a purinergic $\mathrm{P} 2 \mathrm{X} 3$ receptor antagonist, currently under study in the OVADER trial (NCT04545580), a randomized, placebo-controlled, double-blind, proof-ofconcept study to assess its efficacy and safety in patients with OAB and UUI. ${ }^{113}$ P2X3 ionotropic receptors (P2X3R), belonging to the $\mathrm{P} 2$ purinergic receptor family, are expressed in sensory neurons and activated by extracellular ATP with an important role in nociception and sensory hypersensitization. ${ }^{114}$ P2X3Rs are expressed also into the lamina propria, urothelium and detrusor smooth muscle of urinary bladder, and it has been demonstrated that ATP dose-dependently stimulated bladder overactivity in conscious rats and this effect was antagonized by TNPATP. ${ }^{115}$ Hence, P2X3R antagonists are recognized as potential drugs to treat overactive bladder.

\section{Conclusion}

When behavioral therapy fails, antimuscarinics and beta3 -agonists both represent the first-line pharmacological therapy for urgency urinary incontinence. Novel antimuscarinic agents with higher affinity for M3 receptors and lower impact on cognitive function may provide unique options to patients intolerant to the most common AEs and to the elderly. Waiting for $\beta 3$-AR agonist head-to-head trials, a recent indirect treatment comparison showed that the newly FDAapproved vibegron was associated with significantly greater improvements in total incontinence episodes compared with mirabegron, along with a safer profile in terms of drug-drug interactions. Combination therapy represents a non-invasive alternative treatment to UUI refractory to first-line monotherapy, and growing evidence, particularly on the association of AMs and beta-3-agonists, seems to go in this direction. Advances in the research to improve the efficacy/tolerability profile of botulinum toxin, through innovative and less invasive routes of administration, are exciting. Several emerging compounds are in the pipeline and, in the next few years, they may represent a new way to treat urinary incontinence, overcoming the limitations of currently approved drugs.

It has been suggested that idiopathic OAB is a heterogeneous condition encompassing several phenotypes with multiple potential pathophysiological mechanisms. ${ }^{116}$ Identification of these subtypes in clinical practice may allow tailoring of $\mathrm{OAB}$ treatment. The ability to identify the best drug for a specific OAB phenotype could be the real gamechanger of the future, rather than the discovery of new molecules. The International Consultation on Incontinence Research Society (ICI-RS) stressed the need for new research exploring $\mathrm{OAB}$ phenotyping through urodynamics, functional brain imaging and psychology. ${ }^{117}$

\section{Abbreviations}

UI, urinary incontinence; SUI, stress urinary incontinence; UUI, urgency urinary incontinence; MUI, mixed urinary incontinence; OAB, overactive bladder syndrome; DO, detrusor overactivity; RCT, randomize clinical trial; AEs, adverse effects; TEAEs, treatment-emergent adverse events.

\section{Disclosure}

The authors report no conflicts of interest in this work.

\section{References}

1. Abrams P, Cardozo L, Fall M, et al. The standardisation of terminology of lower urinary tract function: report from the standardisation sub-committee of the international continence society. Neurourol Urodyn. 2002;21(2):167-178. doi:10.1002/ nau. 10052

2. Fantl AJ. Urinary Incontinence in Adults: Acute and Chronic Management/Urinary Incontinence in Adults. Guideline Panel Update. Rockville (MD): U.S. Department of Health and Human Services; 1996. Agency for Health Care Policy and Research; Clinical Practice Guideline Number 2: AHCPR publication no. 96-0682.

3. Ebbesen MH, Hunskaar S, Rortveit G, et al. Prevalence, incidence and remission of urinary incontinence in women: longitudinal data from the Norwegian HUNT study (EPINCONT). BMC Urol. 2013;13(1):27. doi:10.1186/1471-2490-13-27

4. Sacco E, Prayer-Galetti T, Pinto F, et al. Urinary incontinence after radical prostatectomy: incidence by definition, risk factors and temporal trend in a large series with a long-term follow-up. BJU Int. 2006;97(6):1234-1241. doi:10.1111/ j.1464-410X.2 006.06185.x

5. Cannon T, Chancellor M. Pharmacotherapy for stress urinary incontinence. Rev Urol. 2003;5:135-141.

6. Sacco E, Tienforti D, D'Addessi A, et al. Social, economic, and health utility considerations in the treatment of overactive bladder. Open Access J Urol. 2010;2:11-243. doi:10.2147/ OAJU.S4166

7. Sacco E. Physiopathology of overactive bladder syndrome. Urologia. 2012;79(1):24-35. doi:10.5301/RU.2012.8972

8. Bientinesi R, Sacco E. Managing urinary incontinence in women a review of new and emerging pharmacotherapy. Expert Opin Pharmacother. 2018;19(18):1989-1997. doi:10.1080/ 14656566.2018.1532502

9. Anderson RU, Mobley D, Blank B, Saltzstein D, Susset J, Brown JS. Once daily controlled versus immediate release oxybutynin chloride for urge urinary incontinence. OROS Oxybutynin Study Group. J Urol. 1999;161(6):1809-1812. doi:10.1016/S0022-5347(05)68810-6

10. Caulfield MP, Birdsall NJ. International union of pharmacology. XVII. Classification of muscarinic acetylcholine receptors. Pharmacol Rev. 1998;50:279-290. 
11. Goepel M, Gronewald A, Krege S, Michel MC. Muscarinic receptor subtypes in porcine detrusor: comparison with humans and regulation by bladder augmentation. Urol Res. 1998;26 (2):149-154. doi:10.1007/s002400050038

12. Abrams P, Andersson KE, Buccafusco JJ, et al. Muscarinic receptors: their distribution and function in body systems, and the implications for treating overactive bladder. $\mathrm{Br} J$ Pharmacol. 2006a;148(5):565-578. doi:10.1038/sj.bjp.0706780

13. Yamanishi T, Kaga K, Fuse M, Shibata C, Kamai T, Uchiyama T. The role of muscarinic receptor subtypes on carbachol-induced contraction of normal human detrusor and overactive detrusor associated with benign prostatic hyperplasia. J Pharmacol Sci. 2015;128(2):65-70. doi:10.1016/j.jphs.2015.05.005

14. Andersson KE. Antimuscarinics for treatment of overactive bladder. Lancet Neurol. 2004;3(1):46-53. doi:10.1016/S14744422(03)00622-7

15. Chapple CR, Khullar V, Gabriel Z, Muston D, Bitoun CE, Weinstein $\mathrm{D}$. The effects of antimuscarinic treatments in overactive bladder: an update of a systematic review and meta-analysis. Eur Urol. 2008;54(3):543-562. doi:10.1016/j.eururo.2008.06.047

16. Buser N, Ivic S, Kessler TM, Kessels AG, Bachmann LM. Efficacy and adverse events of antimuscarinics for treating overactive bladder: network meta-analyses. Eur Urol. 2012;62 (6):1040-1060. doi:10.1016/j.eururo.2012.08.060

17. Lightner DJ, Gomelsky A, Souter L, Vasavada SP. Diagnosis and treatment of overactive bladder (Non-Neurogenic) in adults: AUA/SUFU guideline amendment 2019. J Urol. 2019;202 (3):558-563. doi:10.1097/JU.0000000000000309

18. Herbison P, McKenzie JE. Which anticholinergic is best for people with overactive bladders? A network meta-analysis. Neurourol Urodyn. 2018;38(2):1-10.

19. Cartwright R, Cardozo L. Transdermal oxybutynin: sticking to the facts. Eur Urol. 2007;51(4):907-914. doi:10.1016/j.eururo.2 006.11 .033

20. Ouslander JG, Wood AJJ. Management of overactive bladder. $N$ Engl J Med. 2004;350(8):786-799. doi:10.1056/NEJMra03 2662

21. Pakulski C, Drobnik L, Millo B. Age and sex as factors modifying the function of the blood-cerebrospinal fluid barrier. Med Sci Monitor. 2000;6:314-318.

22. Richardson K, Fox C, Maidment I, et al. Anticholinergic drugs and risk of dementia: case-control study. BMJ. 2018;361:k1315. doi:10.1136/bmj.k1315

23. Risacher SL, McDonald BC, Tallman EF, et al. Association between anticholinergic medication use and cognition, brain metabolism, and brain atrophy in cognitively normal older adults. JAMA Neurol. 2016;73(6):721-732. doi:10.1001/jamaneurol.2016.0580

24. Dmochowski RR, Thai S, Iglay K, et al. Increased risk of incident dementia following use of anticholinergic agents: a systematic literature review and meta-analysis. Neurourol Urodyn. 2021;40 (1):28-37. doi:10.1002/nau.24536

25. Wagg A, Arumi D, Herschorn S, et al. A pooled analysis of the efficacy of fesoterodine for the treatment of overactive bladder, and the relationship between safety, co-morbidity and polypharmacy in patients aged 65 years or older. Age Ageing. 2017;46:620-626.

26. Wagg A, Dale M, Tretter R, Stow B, Compion G. Randomized, multicentre, placebo-controlled, double-blind crossover study investigating the effect of solifenacin and oxybutynin in elderly people with mild cognitive impairment: the SENIOR study. Eur Urol. 2013;64(1):74-81. doi:10.1016/j.eururo.2013.01.002

27. Staskin D, Kay G, Tannenbaum C, et al. Trospium chloride has no effect on memory testing and is assay undetectable in the central nervous system of older patients with overactive bladder. Int J Clin Pract. 2010;64(9):1294-1300. doi:10.1111/j.17421241.2010.02433.x
28. Yonguc T, Sefik E, Inci I, et al. Randomized, controlled trial of fesoterodine fumarate for overactive bladder in Parkinson's disease. World J Urol. 2020;38(8):2013-2019. doi:10.1007/s00345-01902981-7

29. Homma Y, Yamaguchi T, Yamaguchi O. A randomized, doubleblind, placebo-controlled Phase II dose-finding study of the novel anti-muscarinic agent imidafenacin in Japanese patients with overactive bladder. Int J Urol. 2008;15(9):809-815. doi:10.1111/ j.1442-2042.2008.02104.x

30. Pushkar DY, Kasyan GR, Kolontarev KB, Sharvadze GG, Mukhametshina EI. Randomized, open-label, tolterodine-controlled, comparative study of the novel antimuscarinic agent imidafenacin in patients with overactive bladder. Neurourol Urodyn. 2019;38 (5):1313-1321. doi:10.1002/nau.23980

31. Wu JP, Peng L, Zeng X, et al. Is imidafenacin an alternative to current antimuscarinic drugs for patients with overactive bladder syndrome? Int Urogynecol J. 2020;32(5). doi:10.1007/s00192-020-04329-x

32. Salcedo C, Davalillo S, Cabellos J, et al. In vivo and in vitro pharmacological characterization of SVT-40776, a novel M3 muscarinic receptor antagonist, for the treatment of overactive bladder. Br J Pharmacol. 2009;156(5):807-817. doi:10.1111/ j.1476-5381.2008.00082.x

33. Song M, Kim JH, Lee KS, et al. The efficacy and tolerability of tarafenacin, a new muscarinic acetylcholine receptor M3 antagonist in patients with overactive bladder; randomized, double-blind, placebo-controlled phase 2 study. Int J Clin Pract. 2015;69(2):242-250. doi:10.1111/ijcp.12540

34. Sacco E, Bientinesi R, Tienforti D, et al. Discovery history and clinical development of mirabegron for the treatment of overactive bladder and urinary incontinence. Expert Opin Drug Discov. 2014;9 (4):433-448. doi:10.1517/17460441.2014.892923

35. Chapple CR, Cardozo L, Nitti VW, Siddiqui E, Michel MC. Mirabegron in overactive bladder: a review of efficacy, safety, and tolerability. Neurourol Urodyn. 2014;33(1):17-30. doi:10.1002/ nau. 22505

36. Sacco E, Bientinesi R. Mirabegron: a review of recent data and its prospects in the management of overactive bladder. Ther $A d v$ Urol. 2012;4(6):315-324. PMID: 23205058; PMCID: PMC3491758. doi:10.1177/1756287212457114

37. Ko KJ, Choo MS, Chang YS, Kim JC, Lee KS. A multicenter prospective study for overactive bladder patient treatment satisfaction with mirabegron after being unsatisfied with antimuscarinic therapy (FAVOR study). Neurourol Urodyn. 2020;39 (8):2417-2424. doi:10.1002/nau.24505

38. Rosa GM, Ferrero S, Nitti VW, Wagg A, Saleem T, Chapple CR. Cardiovascular safety of $\beta 3$-adrenoceptor agonists for the treatment of patients with overactive bladder syndrome. Eur Urol. 2016;69(2):311-323. doi:10.1016/j.eururo.2015.09.007

39. White WB, Siddiqui E, Tat T, Franks B, Schermer CR. Cardiovascular safety of mirabegron: analysis of an integrated clinical trial database of patients with overactive bladder syndrome. $J$ Am Soc Hypertens. 2018;12(11):768-778.e1. doi:10.1016/j.jash.2018.08.001

40. Kelleher C, Hakimi Z, Zur R, et al. Efficacy and tolerability of mirabegron compared with antimuscarinic monotherapy or combination therapies for overactive bladder: a systematic review and network meta-analysis. Eur Urol. 2018;74(3):324-333. doi:10.1016/j.eururo.2018.03.020

41. Soda T, Tashiro Y, Koike S, Ikeuchi R, Okada T. Overactive bladder medication: persistence, drug switching, and reinitiation. Neurourol Urodyn. 2020;39(8):2527-2534. doi:10.1002/nau.24527

42. Herschorn S, Staskin D, Schermer CR, Kristy RM, Wagg A. Safety and tolerability results from the PILLAR study: a Phase IV, double-blind, randomized, placebo-controlled study of mirabegron in patients $\geq 65$ years with overactive bladder-wet. Drugs Aging. 2020;37(9):665-676. doi:10.1007/s40266-020-00783-w 
43. Griebling TL, Campbell NL, Mangel J, et al. Effect of mirabegron on cognitive function in elderly patients with overactive bladder: moCA results from a Phase 4 randomized, placebo-controlled study (PILLAR). BMC Geriatr. 2020;20(1):109. doi:10.1186/ s12877-020-1474-7

44. Edmondson SD, Zhu C, Kar NF, et al. Discovery of vibegron: a potent and selective $\beta 3$ adrenergic receptor agonist for the treatment of overactive bladder. $J$ Med Chem. 2016;59 (2):609-623. doi:10.1021/acs.jmedchem.5b01372

45. Yoshida M, Takeda M, Gotoh M, Nagai S, Kurose T. Vibegron, a novel potent and selective $\beta 3$-adrenoreceptor agonist, for the treatment of patients with overactive bladder: a randomized, double-blind, placebo-controlled Phase 3 study. Eur Urol. 2018;73 (5):783-790. doi:10.1016/j.eururo.2017.12.022

46. Yoshida M, Takeda M, Gotoh M, et al. Efficacy of vibegron, a novel $\beta 3$-adrenoreceptor agonist, on severe urgency urinary incontinence related to overactive bladder: post hoc analysis of a randomized, placebo-controlled, double-blind, comparative phase 3 study. BJU Int. 2020;125(5):709-717. doi:10.1111/ bju. 15020

47. Mitcheson HD, Samanta S, Muldowney K, et al. Vibegron (RVT-901/MK-4618/KRP-114V) administered once daily as monotherapy or concomitantly with tolterodine in patients with an Overactive bladder: a multicenter, Phase IIb, randomized, double-blind, controlled trial. Eur Urol. 2019;75(2):274-282. doi:10.1016/j.eururo.2018.10.006

48. Staskin D, Frankel J, Varano S, Shortino D, Jankowich R, Mudd PN Jr. International Phase III, randomized, double-blind, placebo and active controlled study to evaluate the safety and efficacy of vibegron in patients with symptoms of overactive bladder: EMPOWUR. $J$ Urol. 2020;204(2):316-324. doi:10.1097/JU.0000000000000807

49. Warren K, Burden H, Abrams P. Mirabegron in overactive bladder patients: efficacy review and update on drug safety. Ther $A d v$ Drug Saf. 2016;7(5):204-216. doi:10.1177/2042098616659412

50. Kennelly MJ, Rhodes T, Girman CJ, Thomas E, Shortino D, Mudd PN Jr. Efficacy of vibegron and mirabegron for overactive bladder: a systematic literature review and indirect treatment comparison [published online ahead of print, 2021 Sep 18]. $A d v$ Ther. 2021. doi:10.1007/s12325-021-01902-8

51. Ohlstein EH, von Keitz A, Michel MC. A multicenter, doubleblind, randomized, placebo-controlled trial of the $\beta 3$-adrenoceptor agonist solabegron for overactive bladder. Eur Urol. 2012;62 (5):834-840. doi:10.1016/j.eururo.2012.05.053

52. Maruyama I, Yonekubo S, Tatemichi S, et al. Effects of ritobegron (KUC-7483), a novel $\beta 3$-adrenoceptor agonist, on both rat bladder function following partial bladder outlet obstruction and on rat salivary secretion: a comparison with the effects of tolterodine. J Smooth Muscle Res. 2012;48(5-6):115-124. doi:10.1540/ jsmr.48.115

53. Tzoumas N, Farrah TE, Dhaun N, Webb DJ. Established and emerging therapeutic uses of PDE type 5 inhibitors in cardiovascular disease. $\mathrm{Br} \quad \mathrm{J}$ Pharmacol. 2020;177(24):5467-5488. doi:10.1111/bph.14920

54. Lee WC, Chiang PH, Tain YL, et al. Sensory dysfunction of bladder mucosa and bladder oversensitivity in a rat model of metabolic syndrome. PLoS One. 2012;7(9):e45578. doi:10.1371/ journal.pone. 0045578

55. Lee WC, Leu S, Wu KLH, Tain YL, Chuang YC, Chan JYH. Tadalafil ameliorates bladder overactivity by restoring insulin-activated detrusor relaxation via the bladder mucosal IRS/PI3K/AKT/eNOS pathway in fructose-fed rats. Sci Rep. 2021;11(1):8202. doi:10.1038/s41598-021-87505-3

56. Dell'Atti L. Efficacy of Tadalafil once daily versus Fesoterodine in the treatment of overactive bladder in older patients. Eur Rev Med Pharmacol Sci. 2015;19(9):1559-1563.
57. Chen H, Wang F, Yu Z, et al. Efficacy of daily low-dose tadalafil for treating overactive bladder: results of a randomized, double-blind, placebo-controlled trial. Urology. 2017;100:59-64. doi:10.1016/j.urology.2016.11.008

58. Giuliano FA, Lamb J, Crossland A, Haughie S, Ellis P, Tamimi NA. A placebo-controlled exploratory study investigating the efficacy and safety of the phosphodiesterase type 5 inhibitor UK-369,003 for the treatment of men with storage lower urinary tract symptoms associated with a clinical diagnosis of overactive bladder. BJU Int. 2010;106(5):666-673. doi:10.1111/j.1464410X.2010.09205.x

59. Drake MJ, Chapple C, Esen AA, et al. Efficacy and safety of mirabegron add-on therapy to solifenacin in incontinent overactive bladder patients with an inadequate response to initial 4Week solifenacin monotherapy: a randomized double-blind multicentre phase 3B study (BESIDE). Eur Urol. 2016;70(1):136-145. doi:10.1016/j.eururo.2016.02.030

60. Herschorn S, Chapple CR, Abrams P, et al. Efficacy and safety of combinations of mirabegron and solifenacin compared with monotherapy and placebo in patients with overactive bladder (SYNERGY study). BJU Int. 2017;120(4):562-575. doi:10.1111/bju.13882

61. Abrams P, Kelleher C, Staskin D, et al. Combination treatment with mirabegron and solifenacin in patients with overactive bladder: efficacy and safety results from a randomized, doubleblind, dose-ranging, phase 2 study (Symphony). Eur Urol. 2015;67 (3):577-588. doi:10.1016/j.eururo.2014.02.012

62. Gibson W, MacDiarmid S, Huang M, et al. Treating overactive bladder in older patients with a combination of Mirabegron and Solifenacin: a prespecified analysis from the BESIDE study. Eur Urol Focus. 2017;3(6):629-638. doi:10.1016/j.euf.2017.08.008

63. Yamanishi T, Kaga K, Sakata K, et al. A randomized controlled study of the efficacy of tadalafil monotherapy versus combination of tadalafil and mirabegron for the treatment of persistent overactive bladder symptoms in men presenting with lower urinary tract symptoms (CONTACT Study). Neurourol Urodyn. 2020;39 (2):804-812. doi:10.1002/nau.24285

64. Wang CC, Jiang YH, Kuo HC. Efficacy and adherence of flexibly adding on a second antimuscarinic agent for patients with refractory overactive bladder. Low Urin Tract Symptoms. 2017;9 (1):27-32. doi:10.1111/luts. 12103

65. Kosilov KV, Loparev SA, Ivanovskaya MA, Kosilova LV. Randomized controlled trial of cyclic and continuous therapy with trospium and solifenacin combination for severe overactive bladder in elderly patients with regard to patient compliance. Ther Adv Urol. 2014;6(6):215-223. doi:10.1177/ 1756287214544896

66. Chancellor MB, Yehoshua A, Waweru C, et al. Limitations of anticholinergic cycling in patients with overactive bladder $(\mathrm{OAB})$ with urinary incontinence (UI): results from the CONsequences of Treatment Refractory Overactive bLadder (CONTROL) study. Int Urol Nephrol. 2016;48(7):1029-1036. doi:10.1007/s11255-0161277-0

67. Sacco E, Pinto F, Bassi P. Emerging pharmacological targets in overactive bladder therapy: experimental and clinical evidences. Int Urogynecol J Pelvic Floor Dysfunct. 2008;19(4):583-598. doi:10.1007/s00192-007-0529-z

68. Chapple C, Sievert K-D, MacDiarmid S, et al. OnabotulinumtoxinA $100 \mathrm{U}$ significantly improves all idiopathic overactive bladder symptoms and quality of life in patients with overactive bladder and urinary incontinence: a randomised, double-blind, placebo-controlled trial. Eur Urol. 2013;64(2):249. doi:10.1016/j.eururo.2013.04.001

69. Nitti VW, Dmochowski R, Herschorn S, et al. OnabotulinumtoxinA for the treatment of patients with overactive bladder and urinary incontinence: results of a Phase 3, randomized, placebo controlled trial. J Urol. 2013;189(6):2186. doi:10.1016/j.juro.2012.12.022 
70. Herschorn S, Kohan A, Aliotta P, et al. The efficacy and safety of onabotulinumtoxinA or Solifenacin compared with placebo in Solifenacin naïve patients with refractory overactive bladder: results from a multicenter, randomized, double-blind Phase $3 \mathrm{~b}$ trial. $J$ Urol. 2017;198(1):167-175. doi:10.1016/j.juro.201 7.01.069

71. Ferreira RS, D'Ancona CAL, Oelke M, Carneiro MR. Intradetrusor onabotulinumtoxinA injections are significantly more efficacious than oral oxybutynin for treatment of neurogenic detrusor overactivity: results of a randomized, controlled, 24-week trial. Einstein. 2018;16(3):eAO4207. doi:10.1590/ S1679-45082018AO4207

72. Nitti VW, Ginsberg D, Sievert KD, et al. Durable efficacy and safety of long-term onabotulinumtoxinA treatment in patients with overactive bladder syndrome: final results of a 3.5-year study. $J$ Urol. 2016;196(3):791-800. doi:10.1016/j.juro.201 6.03.146

73. Lozano-Ortega G, Walker D, Rogula B, et al. The relative efficacy and safety of Mirabegron and OnabotulinumtoxinA in patients with overactive bladder who have previously been managed with an Antimuscarinic: a network meta-analysis. Urology. 2019;127:1-8. doi:10.1016/j.urology.2019.02.005

74. Mangera A, Andersson KE, Apostolidis A, et al. Contemporary management of lower urinary tract disease with botulinum toxin A: a systematic review of botox (onabotulinumtoxinA) and dysport (abobotulinumtoxinA). Eur Urol. 2011;60(4):784-795. doi:10.1016/j.eururo.2011.07.001

75. Peyronnet B, Castel-Lacanal E, Roumiguie M, et al. Intradetrusor injections of onabotulinum toxin A (Botox ${ }^{\mathbb{B}}$ ) $300 \mathrm{U}$ or 200 $\mathrm{U}$ versus abobotulinum toxin A (Dysport ${ }^{\mathbb{B}}$ ) $750 \mathrm{U}$ in the management of neurogenic detrusor overactivity: a case control study. Neurourol Urodyn. 2017;36(3):734-739. doi:10.1002/nau.23009

76. Bottet F, Peyronnet B, Boissier R, et al. Switch to Abobotulinum toxin A may be useful in the treatment of neurogenic detrusor overactivity when intradetrusor injections of Onabotulinum toxin A failed. Neurourol Urodyn. 2018;37(1):291-297. doi:10.1002/ nau. 23291

77. Coelho A, Cruz F, Cruz CD, Avelino A. Spread of onabotulinumtoxinA after bladder injection. Experimental study using the distribution of cleaved SNAP-25 as the marker of the toxin action. Eur Urol. 2012;61(6):1178. doi:10.1016/j. eururo.2012.01.046

78. Mushrush DJ, Koteiche HA, Sammons MA, Link AJ, McHaourab HS, Lacy DB. Studies of the mechanistic details of the pH-dependent association of botulinum neurotoxin with membranes. $J$ Biol Chem. 2011;286(30):27011-27018. doi:10.1074/jbc.M111.256982

79. Chuang YC, Tyagi P, Huang CC, et al. Urodynamic and immunohistochemical evaluation of intravesical botulinum toxin A delivery using liposomes. J Urol. 2009;182(2):786-792. doi:10.1016/j.juro.2009.03.083

80. Chuang YC, Kaufmann JH, Chancellor DD, Chancellor MB, Kuo HC. Bladder instillation of liposome encapsulated onabotulinumtoxinA improves overactive bladder symptoms: a prospective, multicenter, double-blind, randomized trial. J Urol. 2014;192(6):1743-1749. doi:10.1016/j.juro.2014.07.008

81. Tyagi P, Li Z, Chancellor M, De Groat WC, Yoshimura N, Huang L. Sustained intravesical drug delivery using thermosensitive hydrogel. Pharm Res. 2004;21(5):832. doi:10.1023/B: PHAM.0000026436.62869.9c

82. Rappaport YH, Zisman A, Jeshurun-Gutshtat M, et al. Safety and feasibility of intravesical instillation of Botulinum toxin-A in hydrogel-based slow-release delivery system in patients with interstitial cystitis-bladder pain syndrome: a pilot study. Urology. 2018;114:60-65. doi:10.1016/j.urology.201 7.12 .028
83. Chen D, Song D, Wientjes MG, Au JL. Effect of dimethyl sulfoxide on bladder tissue penetration of intravesical paclitaxel. Clin Cancer Res. 2003;9(1):363-369.

84. Petrou SP, Parker AS, Crook JE, Rogers A, Metz-Kudashick D, Thiel DD. Botulinum a toxin/dimethyl sulfoxide bladder instillations for women with refractory idiopathic detrusor overactivity: a phase 1/2 study. Mayo Clin Proc. 2009;84(8):702-706. doi:10.1016/S0025-6196(11)60520-X

85. Cetinel S, Ercan F, Sirvanci S, et al. The ameliorating effect of melatonin on protamine sulfate induced bladder injury and its relationship to interstitial cystitis. $J$ Urol. 2003;169 (4):1564-1568. doi:10.1097/01.ju.0000049649.80549.17

86. Khera M, Somogyi GT, Salas NA, Kiss S, Boone TB, Smith CP. In vivo effects of botulinum toxin A on visceral sensory function in chronic spinal cord-injured rats. Urology. 2005;66(1):208-212. doi:10.1016/j.urology.2005.01.055

87. Asai T, Tsuzuku T, Takahashi $\mathrm{S}$, et al. Cell-penetrating peptide-conjugated lipid nanoparticles for siRNA delivery. Biochem Biophys Res Commun. 2014;444(4):599-604. doi:10.1016/j.bbrc.2014.01.107

88. Nagai J, Komeda T, Katagiri Y, Yumoto R, Takano $M$. Characterization of protamine uptake by opossum kidney epithelial cells. Biol Pharm Bull. 2013;36(12):1942-1949. doi:10.1248/bpb. b13-00553

89. Tyagi P, Banerjee R, Basu S, Yoshimura N, Chancellor M, Huang L. Intravesical antisense therapy for cystitis using TAT-peptide nucleic acid conjugates. Mol Pharm. 2006;3 (4):398. doi:10.1021/mp050093x

90. Glogau R, Blitzer A, Brandt F, Kane M, Monheit GD, Waugh JM. Results of a randomized, double-blind, placebo-controlled study to evaluate the efficacy and safety of a botulinum toxin type A topical gel for the treatment of moderate-to-severe lateral canthal lines. J Drugs Dermatol. 2012;11(1):38-45.

91. Kajbafzadeh AM, Ahmadi H, Montaser-Kouhsari L, Sharifi-Rad L, Nejat F, Bazargan-Hejazi S. Intravesical electromotive botulinum toxin type A administration-part II: clinical application. Urology. 2011;77(2):439-445. doi:10.1016/j.urology.2010.06.003

92. Kajbafzadeh AM, Ahmadi H, Montaser-Kouhsari L, Sabetkish S, Ladi-Seyedian S, Sotoudeh M. Intravesical electromotive administration of botulinum toxin type $\mathrm{A}$ in improving the bladder and bowel functions: evidence for novel mechanism of action. $J$ Spinal Cord Med. 2021;44(1):89-95. doi:10.1080/10790 268.2019.1603490

93. Kodama T, Tomita Y, Koshiyama K, Blomley MJ. Transfection effect of microbubbles on cells in superposed ultrasound waves and behavior of cavitation bubble. Ultrasound Med Biol. 2006;32 (6):905-914. doi:10.1016/j.ultrasmedbio.2006.03.004

94. Chuang YC, Huang TL, Tyagi P, Huang CC. Urodynamic and immunohistochemical evaluation of intravesical botulinum Toxin A delivery using low energy shock waves. J Urol. 2016;196 (2):599-608. doi:10.1016/j.juro.2015.12.078

95. Nambiar AK, Bosch R, Cruz F, et al. EAU guidelines on assessment and nonsurgical management of urinary incontinence. Eur Urol. 2018;73(4):596-609. doi:10.1016/j.eururo.2017.12.031

96. Wróbel A, Serefko A, Woźniak A, et al. Duloxetine reverses the symptoms of overactive bladder co-existing with depression via the central pathways. Pharmacol Biochem Behav. 2020;189:172842. doi:10.1016/j.pbb.2019.172842

97. Mariappan P, Alhasso A, Ballantyne Z, Grant A, N'Dow J. Duloxetine, a serotonin and noradrenaline reuptake inhibitor (SNRI) for the treatment of stress urinary incontinence: a systematic review. Eur Urol. 2007;51:67-74.

98. Bump RC, Voss S, Beardsworth A, Manning M, Zhao YD, Chen W. Long-term efficacy of duloxetine in women with stress urinary incontinence. BJU Int. 2008;102(2):214-218. doi:10.1111/j.1464-410X.2008.07577.x 
99. Mirzaei M, Daneshpajooh A, Anvari SO, Dozchizadeh S, Teimorian M. Evaluation of the clinical efficacy and complications of Duloxetine in comparison to solifenacin in the treatment of overactive bladder disease in women: a randomized clinical trial [published online ahead of print, 2021 Aug 3]. Urol J. 2021. doi:10.22037/uj.v18i.6274

100. Lee MJ, Moon JH, Lee HK, Cho $\mathrm{CH}$, Choi SH, Im WB. Pharmacological characterization of DA-8010, a novel muscarinic receptor antagonist selective for urinary bladder over salivary gland. Eur J Pharmacol. 2019;843:240-250. doi:10.1016/j. ejphar.2018.11.037

101. Choi JB, Jeon SH, Kwon EB, et al. The effects of oral administration of the novel muscarinic receptor antagonist DA-8010 on overactive bladder in rat with bladder outlet obstruction. BMC Urol. 2020;20(1):41. doi:10.1186/s12894-020-00611-8

102. Son H, Kim J, Kim H, et al. MP02-18 efficacy and safety of DA8010, a novel M3 antagonist, in patients with overactive bladder: randomized, double-blind, Phase 2 study. J Urol. 2021;206(Supplement 3):e19. doi:10.1097/ju.00000000000 01963.18

103. Rovner E, Chai TC, Jacobs S, et al. Evaluating the safety and potential activity of URO-902 (hMaxi-K) gene transfer by intravesical instillation or direct injection into the bladder wall in female participants with idiopathic (non-neurogenic) overactive bladder syndrome and detrusor overactivity from two double-blind, imbalanced, placebo-controlled randomized phase 1 trials. Neurourol Urodyn. 2020;39(2):744-753. doi:10.1002/ nau. 24272

104. Wróbel A, Serefko A, Poleszak E, Rechberger T. Fourteen-day administration of corticosterone may induce detrusor overactivity symptoms. Int Urogynecol J. 2016;27(11):1713-1721. doi:10.1007/s00192-016-3027-3

105. Wróbel A, Doboszewska U, Rechberger E, Wlaź P, Rechberger T. SN003, a CRF1 receptor antagonist, attenuates depressive-like behavior and detrusor overactivity symptoms induced by 13-cisretinoic acid in rats. Eur $J$ Pharmacol. 2017;812:216-224. doi:10.1016/j.ejphar.2017.07.010

106. Mukerji G, Yiangou Y, Corcoran SL, et al. Cool and menthol receptor TRPM8 in human urinary bladder disorders and clinical correlations. BMC Urol. 2006;6(1):6. doi:10.1186/1471-2490-6-6

107. Aizawa N, Fujimori Y, Nakanishi O, et al. Efficacy of the combination of KPR-5714, a novel transient receptor potential melastatin 8 (TRPM8) antagonist, and $\beta 3$-adrenoceptor agonist or anticholinergic agent on bladder dysfunction in rats with bladder overactivity. Eur J Pharmacol. 2021;899:173995. doi:10.1016/j. ejphar.2021.173995
108. Freeman RM, Adekanmi O, Waterfield MR, Waterfield AE, Wright D, Zajicek J. The effect of cannabis on urge incontinence in patients with multiple sclerosis: a multicentre, randomized placebo-controlled trial (CAMS-LUTS). Int Urogynecol J. 2006;17(6):636-641. doi:10.1007/s00192-006-0086-X

109. Kavia R, De Ridder D, Constantinescu C, Stott C, Fowler CJ, Constantinescu CS. Randomized controlled trial of Sativex to treat detrusor overactivity in multiple sclerosis. Mult Scler J. 2010;16(11):1349-1359. doi:10.1177/1352458510378020

110. Wróbel A, Szopa A, Serefko A, Poleszak E. A novel alternative in the treatment of detrusor overactivity? In vivo activity of O-1602, the newly synthesized agonist of GPR55 and GPR18 Cannabinoid receptors. Molecules. 2020;25(6):1384. doi:10.3390/molecu les25061384

111. Bientinesi R, Mancuso C, Martire M, et al. KV7 channels in the human detrusor: channel modulator effects and gene and protein expression. Naunyn Schmiedebergs Arch Pharmacol. 2017;390 (2):127-137. doi:10.1007/s00210-016-1312-9

112. Aizawa N, Wakamatsu D, Kida J, et al. Inhibitory effects of retigabine, a Kv7 channel activator, on mechanosensitive primary bladder afferent activities and nociceptive behaviors in rats. Neurourol Urodyn. 2017;36(2):280-285. doi:10.1002/nau.22920

113. National Library of Medicine (U.S.). A randomized, placebo-controlled, double-blind, parallel-group, multi-center, proof-of-concept study to assess the efficacy and safety of BAY 1817080 in patients With Overactive Bladder (OAB) over a 12-week treatment period. Identifier NCT04545580; (2020, September - 2022, February). Available from: https://clinicaltrials.gov/ct2/show/ NCT04545580. Accessed November 7, 2021.

114. Li M, Wang Y, Banerjee R, et al. Molecular mechanisms of human $\mathrm{P} 2 \mathrm{X} 3$ receptor channel activation and modulation by divalent cation bound ATP. Elife. 2019;8:e47060. doi:10.7554/ eLife. 47060

115. Ford AP, Undem BJ. The therapeutic promise of ATP antagonism at $\mathrm{P} 2 \mathrm{X} 3$ receptors in respiratory and urological disorders. Front Cell Neurosci. 2013;7:267. doi:10.3389/fncel.2013.00267

116. Peyronnet B, Mironska E, Chapple C, et al. A comprehensive review of overactive bladder pathophysiology: on the way to tailored treatment. Eur Urol. 2019;75(6):988-1000. doi:10.1016/ j.eururo.2019.02.038

117. Malde S, Apostilidis A, Selai C, et al. Botulinum toxin A for refractory $\mathrm{OAB}$ and idiopathic urinary retention: can phenotyping improve outcome for patients: ICI-RS 2019? Neurourol Urodyn. 2020;39(Suppl 3):S104-S112. doi:10.1002/nau.24207
Clinical Pharmacology: Advances and Applications is an international, peer-reviewed, open access journal publishing original research, reports, reviews and commentaries on all areas of drug experience in humans. The manuscript management system is completely online and includes a very quick and fair peer-review system, which is all easy to use. Visit http://www.dovepress.com/testimonials.php to read real quotes from published authors. 